\title{
The specialisation and sophistication of services exports: The case of the Visegrad countries
}

\author{
Piotr Gabrielczak \\ Department of Macroeconomics, The University of Lodz, \\ Poland \\ piotr.gabrielczak@uni.lodz.pl \\ ORCID0000-0002-9032-7204 \\ Kamila Kuziemska-Pawlak \\ Department of Macroeconomics, The University of Lodz, \\ Poland \\ kamila.kuriemska@,uni.lodz.pl \\ ORCID 0000-0002-7409-8317
}

Abstract. This article analyses exports of services from Czechia, Hungary, Poland and Slovakia between 2010 and 2018, focusing on specialisation and sophistication, also known as complexity. The symmetric revealed comparative advantage index was used to determine fields of specialisation, and PRODY and EXPY indices were used to measure complexity. The results suggest that the Visegrad countries predominantly specialised in the export of relatively unsophisticated services compared to other European Union countries. Still, exports of services from the Visegrad countries were more complex than their real GDP per capita would suggest, and this sophistication is growing. This is due to the convergence of sophistication levels between service categories rather than advances in the structure of services exported by the Visegrad countries. Hence, integration with more developed European Union countries sustained existing fields of specialisation.

Keywords: exports of services, revealed comparative advantage, export complexity, economic integration, Czechia, Hungary, Poland, Slovakia

JEL Classification: F14, F15 


\section{INTRODUCTION}

"Services have become the backbone of the global economy and the most dynamic component of international trade" (World Trade Report, 2019, p. 7). The growing importance of services in global trade stems from their increasing tradability. Thanks to advances in information and telecommunication technologies, many services that were once non-tradable, because they had to be delivered in person or needed face-to-face interaction, have now become tradable, as they can be delivered remotely over long distances.

The growing tradability of services results in the increasing role of services in total trade. Between 2006 and 2018, the trade in commercial services expanded faster (on average 6.5\% per year) than the trade in merchandise (5.6\%). As a result, between 2005 and 2018, the trade in commercial services increased by $119.2 \%$, while the trade in merchandise expanded by $83.9 \%$ (World Trade Report, 2019). Although commercial services still account for only around one-fifth of global trade, their share in world trade is rising - in the 2005-2018 period, it grew from $19.4 \%$ to $22.3 \%$. According to the WTO Global Trade Model, services could account for up to one-third of world trade by 2040. This would be a truly spectacular increase if one takes into account that the share of services in world trade was 9\% in 1970 (World Trade Report, 2019).

The rising role of services in trade also applies to the Visegrad Group (henceforth, V4) countries, namely Czechia, Hungary, Poland and Slovakia. Between 2000 and 2018, the share of services in total exports increased from $18.3 \%$ to $22.2 \%$ in Hungary, from $18.5 \%$ to $21.3 \%$ in Poland, from $9.4 \%$ to $11.9 \%$ in Slovakia, and it decreased marginally in Czechia (from $16.0 \%$ to $15.9 \%$, Eurostat data). The expansion of exports of services in the analysed countries was reinforced by their traditionally high-cost competitiveness and earlier accumulation of human capital. Services contributed substantially to the improvement of the current account balance in the V4 countries. Out of the 2.6 p.p. average improvement in the current account balance to GDP ratio in the V4 countries between 2000 and 2018, 2.2 p.p. were attributed to an increase in the services balance (Eurostat data).

The aim of this paper is to investigate the specialisation and complexity of the V4 countries' exports of services in light of European economic integration. Specialisation simply refers to the revealed comparative advantages, as it is rational for a country to specialise in providing exactly those services that it has a relative advantage in. Export complexity (also called economic complexity), on the other hand, is a term which may refer to two characteristics of international trade. The first is the technological advancement of exported goods (Lall, 2000). The second is the number of components required for production, which is the more frequently used approach popularised by Hausmann, Hwang, and Rodrik (2007) in their seminal paper. Even though both definitions appear to be divergent, they are, in fact, close to equivalent since both characteristics tend to be strongly correlated - more advanced products often require more production steps, thus a wider range of components. Therefore, using terms such as export sophistication or export advancement as synonyms of export complexity seems justified. To the best of our knowledge, this is the first study in the trade literature that links specialisation patterns and the complexity of services exports of the V4 countries.

The problem of revealed comparative advantages in services within the V4 group has been analysed by, e.g. Foster, Hunya, Pindyuk, and Richter (2011), Kuczewska, and Stefaniak-Kopoboru (2016) and Matuszczak (2015), though the last author excluded Hungary. Our period of analysis is 2010-2018, and it overlaps with the periods analysed in the mentioned studies. Due to the methodological changes in the available data pertaining to the introduction of the IMF Balance of Payments and International Investment Position Manual (2009) methodology (henceforth BPM6), our research period could not be directly extended into the past. Since the division of service categories has changed, and as RCA is a base-sensitive measure that 
depends on a reference group, the previous research and this research can be used together to draw only reserved conclusions about the evolution of the revealed comparative advantages in the export of services.

The remainder of the paper is structured as follows. Section 2 provides a literature review regarding the role of services in modern international trade, economic complexity and its role, and the possible effects of integration for a less developed country in terms of complexity. Section 3 describes the data and methodology concerning the measurement of specialisation and sophistication, while section 4 presents the empirical results. Finally, the last section concludes.

\section{LITERATURE REVIEW}

The research presented in the paper combines two popular strands in the economic literature, which are usually developed separately. The first one refers to the role of services in international trade. The second one focuses on economic complexity, which is typically investigated in the context of trade in goods rather than services. In order to offer proper context for both issues, section 2.1 provides a review of the literature on the role of services in international trade, while section 2.2 refers to the literature on economic complexity. The present study also includes a dynamic aspect - the research period of 2000-2018 was highly influenced by the processes of regional integration in Europe. We believe that these processes may have affected the patterns of specialisation and, thus, the obtained levels of export complexity in the V4 countries. The literature on economic integration is vast and has multiple points of focus; therefore, conducting a full survey would be impractical. However, there is a branch of the literature that already links the problems of integration with economic complexity, which is one of our main interests. That is why section 2.3 presents a review of the literature on economic integration, but with reference to the issues of economic complexity.

Our biggest contribution is within the last branch of the literature, which, to the best of our knowledge, still lacks insight into the effects of integration on the complexity of traded services. Moreover, the majority of the empirical evidence is based on data from the most developed countries or large samples of relatively heterogeneous countries; therefore, our focus on the V4 group may also be treated as a novelty.

\subsection{The role of services in modern international trade}

Modern microeconomic models of the so-called "new new trade theory", based on the seminal paper by Melitz (2003) that analysed export decisions from the perspective of productivity, could be employed to investigate the trade in services. Morikawa (2019), using data from a panel of Japanese firms, noticed that service-supplying enterprises are, on average, more productive than goods-supplying enterprises, while exporters of services are more productive than companies that supply services for the domestic market only. Breinlich, and Criscuolo (2011) observed a similar pattern based on data from the UK. They claim that exporters of services are more productive than non-exporters. However, they also make a point that only a small fraction of service-supplying companies engage in export at all. As observed by Anand, Mishra, and Spatafora (2011), only about $10 \%$ of exported value added originates from services. Nevertheless, in recent years, the trend has been for that share to rise over time. Services still play a much more important role in domestic trade than in international exchange, but this gap is closing. Apart from the microeconomic approach, typical for the new new trade theory, research on a macroeconomic level confirms that the export of services is a long-run driver for economic growth. Shieh (2020) investigated that phenomenon on a sample of 89 countries over almost five decades and showed that there is evidence of a strong causality in that direction.

There are a few specific factors that have stimulated growth in the tradability of services in recent decades. One of them is the explosion of the internet and communications technology (Freund \& Weinhold, 2002). Another is the standardisation of and progress in intellectual property rights protection, which in the 
case of services is even more important than in the case of goods (Maskus, 2008). However, the biggest reason seems to arise from the fact that the development of services not only does not hamper the development of the production of goods, but in fact, it is complementary to it. As a result, comparative advantages in services are consistent with those within the industry (Jensen, 2008), and both sectors of the economy develop together and maintain a similar pace of productivity growth (Young, 2014).

However, there are also factors that hamper the growth in the tradability of services. According to Lehman, Tamirisa, and Wieczorek (2003), there are four types of formal barriers for trade in services: quantitative barriers, price-related barriers (e.g. special taxes or tariffs), licensing and certification requirements, and obstacles associated with unequal access to distribution or communication networks. The last two types of barriers are domestic regulations that do not necessarily have to be designed to mitigate market access for foreign service providers, but in many cases, they are more effective at confining the international flow of services than any dedicated cross-border restrictions (Crozet, Milet \& Mirza, 2016).

The introduction of the European common market allowed some services, such as telecommunications or air transport, to develop on an international scale. Yet, in general, its establishment had a limited effect on service tradability. This is because integration on a formal or institutional level is incapable of overcoming the most significant obstacles in the context of services - barriers associated with information asymmetries (Canoy \& Smith, 2008). Moreover, integration in terms of trade in services is not as popular as in the case of trade in goods. As of 2015, only about one-third of existing international trade agreements included clauses concerning services (Sauvé \& Shingal, 2016).

\subsection{Economic complexity and its role}

Export complexity has been a point of focus for the literature concerning international trade since the beginning of the 21st century. Economic complexity is important for the pace and characteristics of economic growth. To start with, Hausman et al. (2007) claimed that more complex products (goods or services) have higher unit profitability. Hence, higher export sophistication may work as an economic growth driver. However, they noticed that this is true only if export streams do not alter international prices. The positive effect may also be limited if the country's currency has a tendency to be overvalued (Anand et al., 2012; Sepehrdoust, Davarikish \& Setarehie, 2019).

Furthermore, economies with structures that are concentrated on more complex goods tend to display lower income inequalities, which arises from the fact that a wider range of workers participate in economic processes and have better bargaining positions. However, this mechanism depends on the level of human capital within the economy. If human capital is low, the labour force is not flexible enough, and the growing demand for highly skilled workers increases unemployment (Lee \& Vu, 2020). However, if the requirements for flexibility are met, and growing complexity improves the situation on the labour market, it also translates to better general health outcomes. $\mathrm{Vu}(2020)$ established that countries with higher economic complexity also demonstrate higher general health levels, and the labour market is the channel through which public health can be improved.

Production and export structures that favour more complex goods are also more environmentally friendly. Romero, and Gramkov (2021), using a sample of 67 countries, found that economies with higher economic complexity demonstrate lower greenhouse gas emissions. This is because complex goods are typically associated with more advanced technologies that produce higher added value and have a smaller carbon footprint. Higher complexity leads to a decline in natural resource rents (Canh, Schinckus \& Thanh, 2020), which should translate to lower relative profitability of trading in raw materials and mitigated supply. On the other hand, it should promote resource-saving technologies. 
Finally, as a supply-side shock can be compensated for by the substitution of inputs, countries with higher economic complexity tend to be more resistant to supply-side shocks, reducing the magnitude of short-term economic fluctuations. This is because a wider range of inputs used for production requires a larger network of contacts. Thus, larger networks reduce transaction costs (Koren \& Tenreyro, 2013).

\subsection{The effects of integration in terms of complexity}

Regional integration leads to structural shifts in the integrating economies, which could result in changes of revealed comparative advantages. One of the most interesting cases is a less developed partner joining an organisation of more developed countries. The literature offers two lines of argumentation in terms of expectations about the evolution of the new partner's export complexity.

The first argument is that integration facilitates increased complexity through the channel of foreign direct investment (FDI). The modern "new new trade theory" provides strong arguments that only the most productive companies engage in FDI. This self-selection mechanism is present both with horizontal FDI (Helpman, Melitz \& Yeaple, 2004) and vertical FDI (Antras \& Helpman, 2004). FDI flows not only mean quantitative increases in capital, but they also usually work as carriers of technological progress. Thanks to regional integration, barriers to the free flow of capital disappear. A new member state typically receives an influx of FDI (Antras \& Foley, 2011), and such inflows are expected to generate an increase in the country's export complexity (see, e.g. Xu \& Lu, 2006; Harding \& Javorcik, 2012; Eck \& Hubert, 2016 for empirical verification). ${ }^{1}$ Inflows of FDI may affect the economy in various ways. Firstly, the presence of foreign affiliates increases competitive pressure, forcing efficiency-seeking on the domestic market (Javorcik, Lo Turco \& Maggioni, 2018). Secondly, FDI often includes transfers of the skilled labour force, which helps to overcome one of the key hampering factors for the development of more advanced sectors - the lack of human capital (Hidalgo \& Hausman, 2009). It is not only inward, but also outward FDI that may have a positive impact because they increase the country's contact with more sophisticated demand and more advanced technology (so-called reverse knowledge spillovers or the exposition effect). However, Zhang, and Chen (2020), using data for Chinese regions, claim that the beneficial effects of (outward) FDI are achievable only if GDP per capita, human capital and research and development commitment are above a certain minimum threshold - in other cases, the effects are wasted.

In the literature, one can also find a completely different line of argumentation, suggesting that regional integration is more likely to cause a reduction in export complexity of the relatively less developed new partner. First of all, Young (1991) claims that integration between partners with different development levels emphasizes their relative differences, forcing the less developed partner to solidify within the comparative advantages associated with traditional, usually less sophisticated, sectors. As a result, relatively advanced sectors become abandoned or neglected, and less advanced sectors prevail. Due to the stagnation of development, integration limits the possibilities for learning-by-doing within the more advanced sectors. According to Galor, and Mountford (2008), since regional integration provides instant access to a significantly larger market, it is easy to generate additional short-run profits only by increasing the scope of business, without any concern for efficiency. Companies are tempted by that opportunity, which leads to a slump in human capital investment, creating a negative shock for complexity.

\footnotetext{
${ }^{1}$ Recent literature developments suggest that in fact the flows of FDI are also motivated by efficiency seeking and that complexity may be one of the attractors of FDI (Sadeghi, Shahrestani, Kiani \& Torabi, 2020). Therefore, as much as it is true that FDI inflow may increase the country's level of economic sophistication, it is also true that investors select host countries with already relatively high levels of complexity.
} 
Gabrielczak, and Serwach published a series of papers that focused on the effects of European integration on the export complexity of the member states (though measured for goods, not services). A study on a panel of 36 countries demonstrated that participating in integrational processes in general significantly increased the levels of export complexity (Serwach \& Gabrielczak, 2021). However, their research into particular cases, namely Estonia, Slovakia and Slovenia, using a synthetic control method, suggests a slightly more intricate relationship. When these countries joined the EU, their sophistication either declined or continue to grow, but with lower dynamics. However, as the integration process continued, leading to monetary integration, the level of complexity increased (Gabrielczak \& Serwach, 2017, 2019, 2020). This may suggest that both groups of mechanisms proposed in the literature are operational, but in chronological order, with hampering mechanisms dominating first and stimulating ones overwhelming in the second phase. It is in line with the findings by Zhang, and Chen (2020), because integration stimulates economic growth. Thus, once the new member states become sufficiently developed, the beneficial effects of FDI might engage, and integration may finally lead to a growth in complexity, which is not possible at first.

\section{METHODOLOGY}

\subsection{Measuring specialisation}

Our measure of sectoral specialisation is based on the Balassa (1965) Index of Revealed Comparative Advantage (RCA). ${ }^{2}$ We calculate the RCA index according to the formula:

$$
R C A_{i j t}=\frac{\frac{x_{i j t}}{\sum_{j} x_{i j t}}}{\frac{\sum_{i} x_{i j t}}{\sum_{j} \Sigma_{i} x_{i j t}}}
$$

where $x_{i j t}$ stands for exports of service category $j$ from country $i$ in period $t$.

The numerator is the share of category $j$ in country $i$ 's exports, while the denominator is the share of category $j$ in the reference group's exports. Hence, the RCA index provides a comparison of a given country's export structure (the nominator) with the reference country group's export structure (the denominator). The RCA index is essentially a normalised export share, and it is calculated for a specific period.

The reference group in this study is the European Union (28, henceforth the EU). The reason behind this choice is the tight integration in terms of trade of the V4 countries with the EU. In 2018, the share of the EU as a destination for the exports of services was $66.7 \%$ in Czechia, $70.7 \%$ in Hungary, $69.5 \%$ in Poland, and $78.5 \%$ in Slovakia.

If the RCA index of a given category in a given country equals 1 , the share of this category in total exports is the same, on average, as in the EU. If the RCA is above (below) 1 , the country is said to have a revealed comparative advantage (disadvantage) in a given category.

2The RCA index is based on the Ricardian comparative advantage concept (Ricardo, 1817). According to the Ricardian model, countries will export goods that their labour (the only production factor in this model) produces relatively efficiently, and import goods that their labour produces relatively inefficiently (Krugman \& Obstfeld, 2009). For an alternative to Balassa's index of RCA, see Costinot, Donaldson, and Komunjer (2010). 
The values of the RCA index cannot be compared on both sides of unity. Hence, we prefer to use the Revealed Symmetric Comparative Advantage (RSCA) index (see Laursen, 1998), which is the following transformation of the RCA index:

$$
R S C A_{i j t}=\frac{R C A_{i j t}-1}{R C A_{i j t}+1}
$$

The RSCA index ranges between -1 and 1 . If the value of the RSCA index exceeds (is below) zero, a country is said to have a revealed comparative advantage (disadvantage).

\subsection{Measuring sophistication}

Our measure of export sophistication is based on the PRODY and EXPY indices proposed by Hausmann et al. (2007). PRODY is an index for complexity of a particular product, or group of products. In our case, products are replaced with services. It is based on the weighted averaging of GDP per capita, so, depending on the selected interpretation of GDP, one could say that it is income- or productivity-based. EXPY, on the other hand, is an index of complexity of national export structures, and it is a weighted average of PRODY values for the goods, or in this case services, that are exported by a given country. That is why in this setup, PRODY is an input into the calculation of EXPY. As stated by Huber (2017), these indices are the most commonly used measures of complexity ${ }^{3}$ due to their simplicity and lack of subjective assumptions from the researcher, such as the manual grouping of countries, for example, which was the case in Lall, Weiss, and Zhang (2006).

We calculate PRODY and EXPY for the export of services, where the EU is the reference group. PRODY is the index of sophistication of service category $j$ in period $t$. It can be expressed as follows:

$$
P R O D Y_{j t}=\sum_{i} \frac{\frac{x_{i j t}}{X_{i t}}}{\sum_{i}^{x_{i j t}} Y_{i t}} Y_{i t}
$$

In our notation, again, $i$ refers to a country and $j$ to a particular service category. $X_{i t}$ is the total export of services from country $i$ in period $t$, while $x_{i j t}$ is the export of service category $j$ from country $i$ in period $t$. Therefore, ${ }^{x_{i j t}} / \mathrm{X}_{i t}$ represents the share of service $j$ in total exports of services from country $i$ in period $t$. $Y_{i t}$ refers to the real GDP per capita of country $i$ in period $t$. As a result, PRODY could be interpreted as the average level of real GDP per capita associated with the exports of service category $j$ in period $t$.

The values of the PRODY index calculated for particular service sectors can be used to calculate EXPY - a sophistication measure for countries. EXPY is the average of the PRODY values associated with particular exported goods or services (as in our case), with export shares working as weights. With the same notation as above, we can express EXPY as follows:

$$
E X P Y_{i t}=\sum_{j} \frac{x_{i j t}}{X_{i t}} P R O D Y_{j t}
$$

\footnotetext{
${ }^{3}$ It should be mentioned that Hausmann et al. (2007) derived their concept of PRODY and EXPY from Michaely (1984), who was one of the first to try to measure export sophistication.
} 
The regular EXPY index is constructed based upon time-variant PRODY measures. In that case, the fluctuations of EXPY may be due to changes within the structure of exports, or changes in PRODY values. Gable, and Mishra (2011) suggest using a modified version of EXPY built upon average (thus, timeinvariant) values of PRODY. In that case, any fluctuations of EXPY over time are due to changes within the structure of the export of services, while PRODY for each service category remains constant. Gable, and Mishra (2011) call that version static EXPY. We utilise both approaches. Furthermore, in order to facilitate the analysis, we normalised the calculated indices using the following formula (herein, illustrated by the example of PRODY):

$$
\text { normalisedPRODY } Y_{j t}=\frac{P R O D Y_{j t}-\overline{\min P R O D Y}}{\overline{\max P R O D Y}-\overline{\min P R O D Y}}
$$

The min PRODY and max PRODY refer to the extreme values of PRODY in the entire sample. Thanks to this normalisation procedure, all PRODY values, which are typically unlimited and of the same order as GDP per capita, have been scaled onto a [0,1] range. The lowest value of PRODY in the entire period becomes 0, while the highest becomes 1. All the other observations are distributed in between. EXPY (both regular and static) are normalised in the same manner.

\subsection{Data}

International trade in services is an important component of the balance of payments' current account. The classification of services according to the International Monetary Fund's BPM6 (Balance of Payments..., 2009) methodology comprises 12 main services categories: 1) manufacturing services on physical inputs owned by others, 2) maintenance and repair services not identified elsewhere (n.i.e.), 3) transport, 4) travel, 5) construction, 6) insurance and pension services, 7) financial services, 8) charges for the use of intellectual property n.i.e., 9) telecommunications, computer and information services, 10) other business services, 11) personal, cultural, and recreational services, 12) government goods and services n.i.e.

Table 1

Services categories

\begin{tabular}{|l|c|c|}
\hline Services categories & BPM6 Code & Acronym \\
\hline Manufacturing services on physical inputs owned by others & SA & PRO \\
\hline Maintenance and repair services n.i.e. & SB & MAI \\
\hline Sea transport & SC1 & SEA \\
\hline Air transport & SC2 & AIR \\
\hline Rail transport & SC3B & RAI \\
\hline Road transport & SC3C & ROA \\
\hline Inland waterway transport & SC3D & INL \\
\hline Postal and courier services & SC4 & POS \\
\hline Travel & SD & TRV \\
\hline Construction & SE & CON \\
\hline Insurance and pension services & SF & INS \\
\hline Financial services & SG & FIN \\
\hline Charges for the use of intellectual property n.i.e. & SH & INT \\
\hline Telecommunications services & SI1 & TEL \\
\hline Computer services & SI2 & COM \\
\hline Information services & SI3 & INF \\
\hline Research and development services & SJ1 & RDI \\
\hline Professional and management consulting services & SJ2 & PRF \\
\hline Technical, trade-related, and other business services & SJ3 & TEC \\
\hline Personal, cultural, and recreational services & SK & PER \\
\hline
\end{tabular}

Source: own elaboration. 
An additional item, services not allocated, can be used for services that cannot be classified under any of the 12 categories mentioned above. The main services categories can be disaggregated into more detailed ones. However, disaggregation leads to the increasing problem of a lack of data. The selection of services that we decided to analyse is presented in Table 1.

The data on international trade in services are sourced from Eurostat. The data is of annual frequency, starting in 2010 and ending in 2018.

\section{EMPIRICAL RESULTS}

\subsection{Analysis of specialisation}

\subsubsection{Czechia}

In 2018, Czechia was relatively specialised in exports of labour-intensive services such as rail and road transport, manufacturing services on physical inputs owned by others (henceforth manufacturing services), maintenance and repair services n.i.e. (henceforth, maintenance and repair services), travel, and construction services. It also revealed a comparative advantage in exports of selected human-capital-intensive services, namely telecommunication, and computer, professional and management consulting services (Figure 1).

Analysing the change in the RSCA index between 2010 and 2018, it is noteworthy that Czechia recorded a decrease in its comparative disadvantage for research and development services. Moreover, while it revealed a comparative disadvantage in telecommunication and in computer services in 2000, in 2018, it revealed a comparative advantage in these categories. Concerning other human-capital-intensive services, between 2000 and 2018, Czechia decreased its revealed comparative disadvantage in personal, cultural, and recreational services.

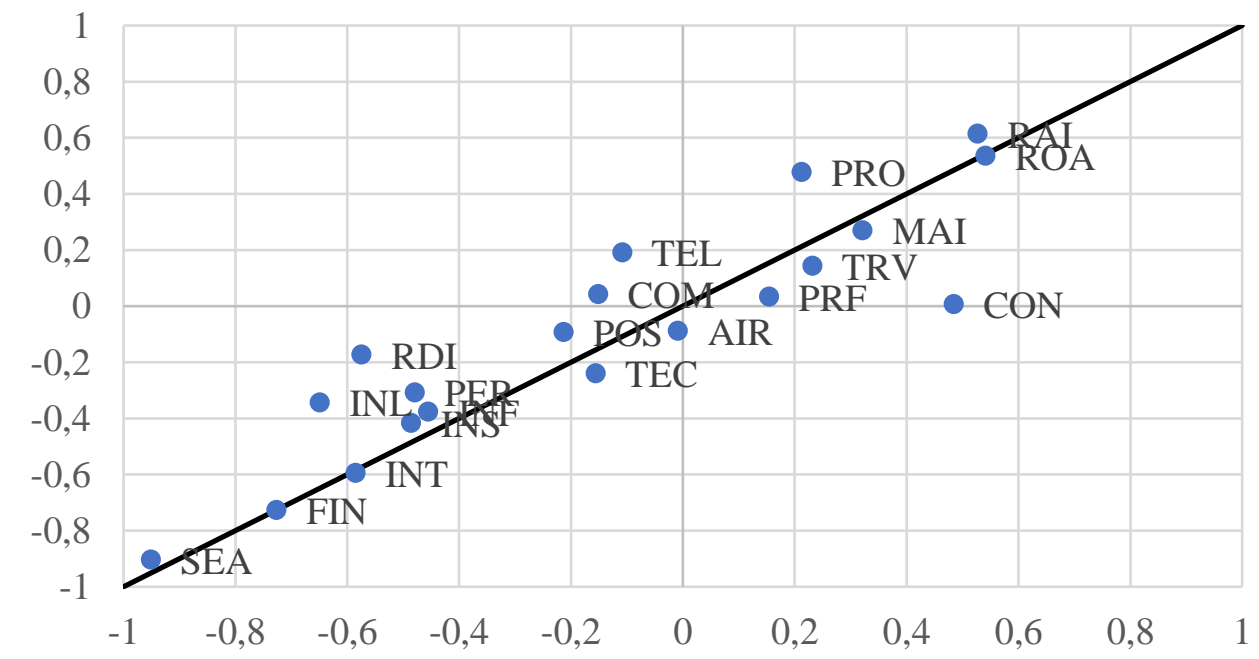

Figure 1. The RSCA index in 2010 (horizontal axis) and 2018 (vertical axis) in Czechia

Note: the 45-degree line facilitates visual analysis, as it indicates points with equal RSCA values in both years. All sectors above the line registered an increase in RSCA, while all the sectors below the line registered a decline in the research period. Source: own elaboration of the Eurostat data.

According to Foster et al. (2011), Matuszczak (2015), and Kuczewska, and Stefaniak-Kopoboru (2016), Czechia has had a stable revealed comparative advantage in transportation services and international travel since the 1990s. Up to 2005, it also had a comparative advantage in personal, cultural, and recreational 
services, which was not regained or sustained. The country also had a comparative advantage in post and telecommunication services, which was lost in the early 2000s only to be reobtained in 2014. It has also been recording a comparative advantage in computer and information services (henceforth, IT services) since 2005 , which at first was not stably maintained, but has been present consistently since 2012. Combining our results with the results of the aforementioned studies allows us to draw some tentative conclusions. First of all, there was a fixed core - Czechia revealed comparative advantages in transportation and travel services before and after EU accession. On the other hand, some of the revealed comparative advantages observed in the 1990s were temporarily mitigated or lost around the period of accession, ${ }^{4}$ although integration also seems to have facilitated the creation of some new fields of relative specialisation.

\subsubsection{Hungary}

In 2018, Hungary was relatively specialised in exports of rail, road, air, and inland waterway transport (Figure 2). Moreover, it revealed a comparative advantage in the export of manufacturing services, maintenance and repair services, as well as travel services. Hungary's relative specialisation was not confined to labourintensive services. It also revealed a comparative advantage in selected human-capital-intensive services. The shares of exports of personal, cultural, and recreational services, and professional and management consulting services in total exports of services from Hungary was higher than the corresponding shares for the EU.

Referring to the change in the relative specialisation between 2010 and 2018, Hungary increased its revealed comparative advantage in air, rail and road transport over that period, as it did with manufacturing services. The revealed comparative advantage in personal, cultural, and recreational services was first observed in 2011, and it strengthened in 2014. Finally, between 2010 and 2018, Hungary's revealed comparative disadvantage in telecommunications services became more apparent, while in 2017, it also lost its revealed comparative advantage in services associated with charges for the use of intellectual property n.i.e (henceforth, charges for the use of intellectual property).

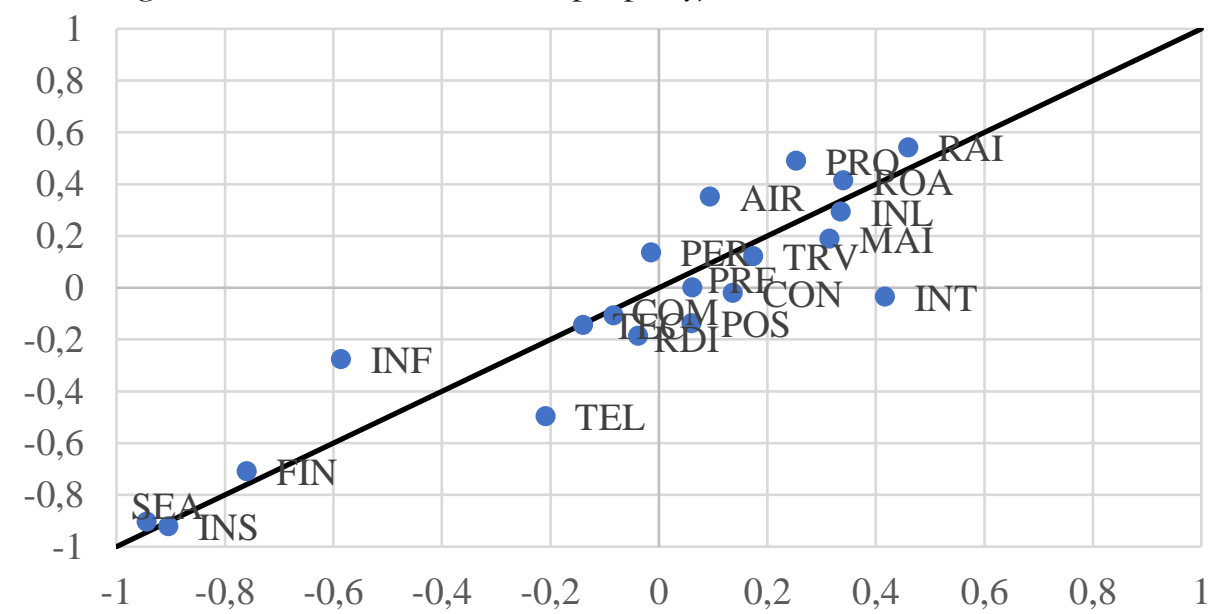

Figure 2. The RSCA index in 2010 (horizontal axis) and 2018 (vertical axis) in Hungary

Note: the 45-degree line facilitates visual analysis, as it indicates points with equal RSCA values in both years. All sectors above the line registered an increase in RSCA, while all the sectors below the line registered a decline in the research period. Source: own elaboration of the Eurostat data.

\footnotetext{
${ }^{4}$ Technically, 2004 is the year when all the V4 countries joined the EU. However, since integration is a scheduled process, it is subject to anticipation. At the same time, it has some lagged effects. Therefore, the impact of EU accession on the V4 countries could be observed both before and after the official accession date.
} 
Kuczewska, and Stefaniak-Kopoboru (2016) noted that Hungary has had a revealed comparative advantage in travel services and personal, cultural, and recreational services since 2000. Meanwhile, Foster et al. (2011) found that Hungary revealed a comparative advantage in terms of charges for the use of intellectual property. According to Kuczewska, and Stefaniak-Kopoboru (2016), immediately or shortly after EU accession, Hungary revealed comparative advantages in business services and IT services, which it held until 2010, while a comparative advantage in transportation first appeared in 2011. To conclude, some of the advantages were maintained throughout the integration process, while others emerged immediately or shortly after EU accession.

\subsubsection{Poland}

In 2018, Poland was relatively specialised in exports of road and rail transport, manufacturing services, construction services, maintenance and repair services, and travel services (Figure 3). Poland's relative specialisation in transport, as well as travel services, was directly linked to its geographical position, namely its location on the external border of the EU. Poland's revealed comparative advantage did not limit itself to labour-intensive services, however, which is reflected in its relative specialisation in exports of professional and management consulting services.

From a longer perspective, it is worth noting that from 2010 to 2018, Poland recorded an increase in the RSCA index for computer services, telecommunication services, personal, cultural, and recreational services, as well as services associated with research and development. Although Poland is still relatively less specialised in the exports of these services than the EU, its revealed comparative disadvantage decreased. As far as labour-intensive services are concerned, Poland increased its revealed comparative advantage in manufacturing services and road transport.

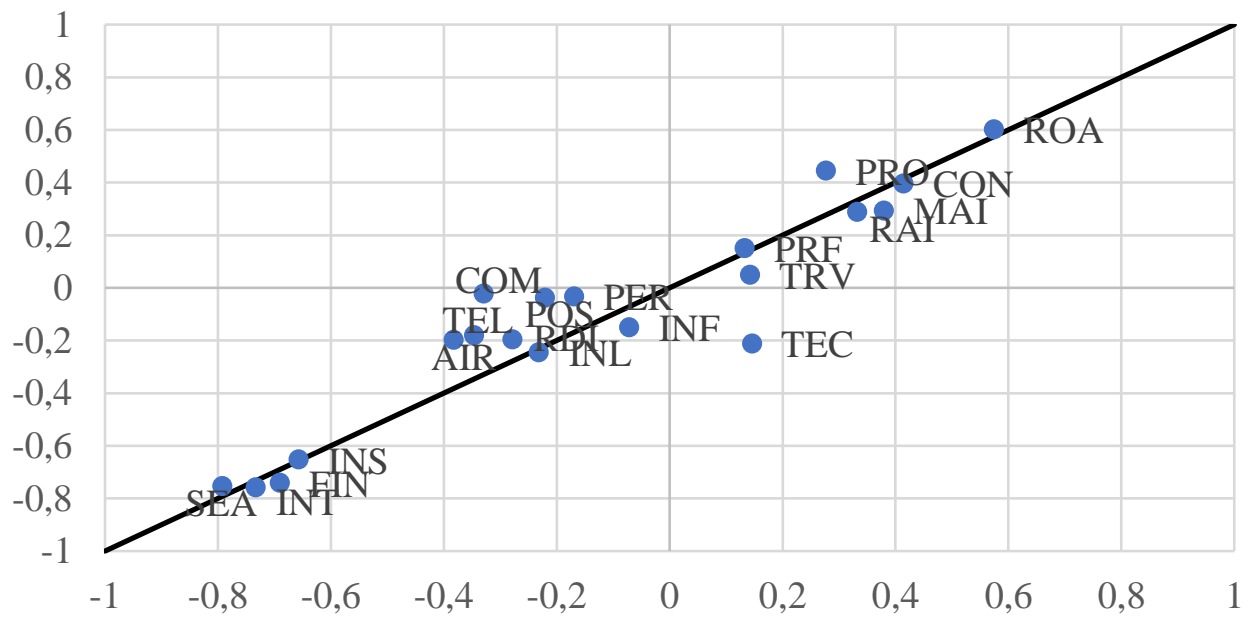

Figure 3. The RSCA index in 2010 (horizontal axis) and 2018 (vertical axis) in Poland

Note: the 45-degree line facilitates visual analysis, as it indicates points with equal RSCA values in both years. All sectors above the line registered an increase in RSCA, while all the sectors below the line registered a decline in the research period.

Source: own elaboration of the Eurostat data.

Before 2010, Poland revealed comparative advantages in transportation, international travel, and construction (Foster et al., 2011; Matuszczak, 2015; Kuczewska \& Stefaniak-Kopoboru, 2016) - these were the core advantages that were maintained until 2018. This was not the case for all the pre-accession comparative advantages, as Poland was the only V4 country to note a revealed comparative advantage in insurance services, although it was lost at the beginning of the $21^{\text {st }}$ century (Foster et al., 2011; Kuczewska \& Stefaniak-Kopoboru, 2016). Accession created new opportunities, too. Some of them turned out to be 
only temporary and not sustainable, e.g. personal, cultural, and recreational services, while others proved to be more durable, as in the case of the revealed comparative advantage in business services (in BPM6, this corresponds with: professional and management consulting services) observed continuously since 2009 (Kuczewska \& Stefaniak-Kopoboru, 2016).

\subsubsection{Slovakia}

Throughout the entire sample period, which in this case uniquely starts in 2013, Slovakia was relatively specialised in the export of rail and road transport, as well as postal and courier services (Figure 4). Other labour-intensive services in which it revealed a comparative advantage included manufacturing services, travel, and maintenance and repair services. Concerning human-capital-intensive services, Slovakia revealed a comparative advantage in professional and management consulting services, telecommunications services, and, since 2017, computer services. One category of services in which Slovakia recorded a substantial decrease in revealed comparative disadvantage in the analysed period was air transport, in which case the RSCA index increased from -0.8 in 2013 to -0.5 in 2018.

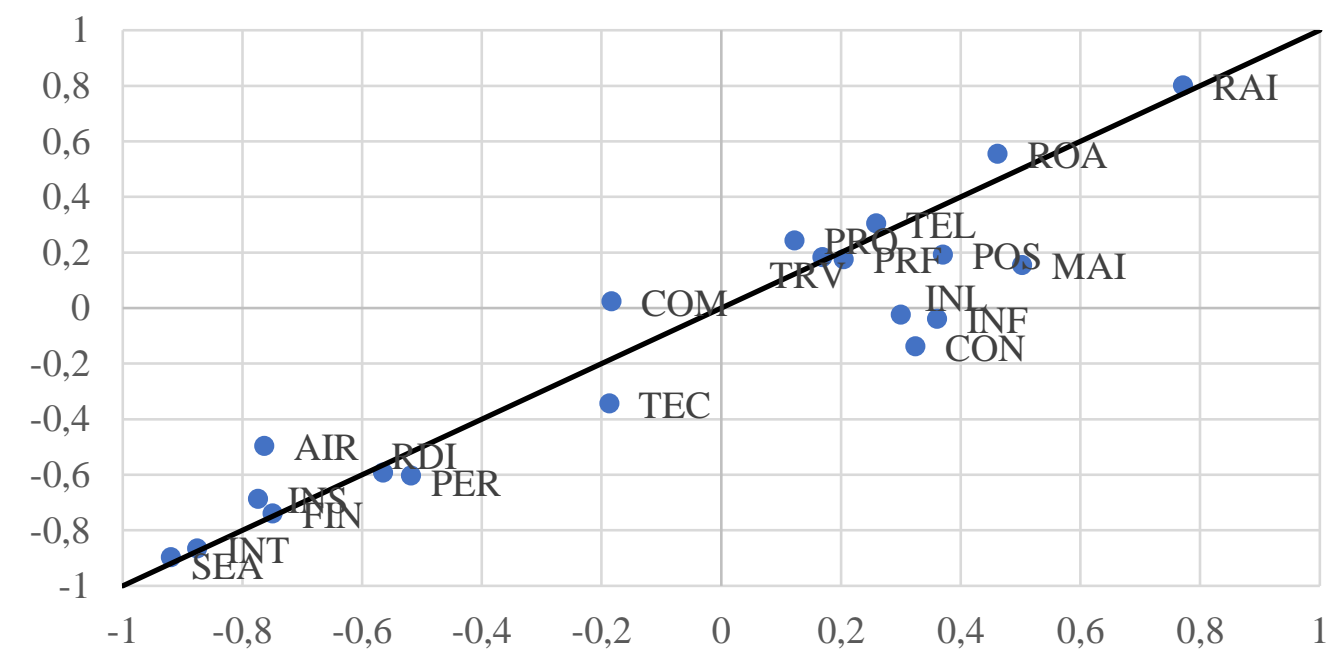

Figure 4. The RSCA index in 2013 (horizontal axis) and 2018 (vertical axis) in Slovakia

Note: the 45-degree line facilitates visual analysis, as it indicates points with equal RSCA values in both years. All sectors above the line registered an increase in RSCA, while all the sectors below the line registered a decline in the research period. Source: own elaboration of the Eurostat data.

Between 2000 and 2012, Slovakia revealed comparative advantages in transport as well as personal, cultural, and recreational services (Matuszczak, 2015), although the latter was lost in 2013 (Kuczewska \& Stefaniak-Kopoboru, 2016). In 2004, when Slovakia joined the EU, it started to reveal comparative advantages in international travel and communication. Since 2009, which was also the year when Slovakia adopted the euro, a revealed comparative advantage in computer services was observed for the first time (Kuczewska \& Stefaniak-Kopoboru, 2016). However, our results suggest that this advantage was not present until 2017, and even in the final two years of the research period, it was not strong, so in this case, our results contradict previous findings.

\subsubsection{The possible roots of specialisation patterns}

The above analysis shows that between 2010 and 2018, the V4 countries were, in general, relatively specialised in exports of labour-intensive services. Examples of these services include transportation 
services, manufacturing services, and maintenance and repair services. This pattern of specialisation could be attributed to the existing model of expansion of the V4 countries' exports, which was largely based on cost competitiveness. In 2018, the ratio of hourly labour costs in services of the business economy in Czechia, Hungary, Poland, and Slovakia accounted for, respectively, $47.8 \%, 37.4 \%, 37.0 \%$, and $43.3 \%$ of the corresponding costs in the EU28 (Eurostat data).

Moreover, analysing the period between 2010 and 2018, one can notice that the V4 countries recorded an increase in the RSCA index in the selected human-capital-intensive services. For instance, Czechia, Poland, and Slovakia recorded an increase in the index in computer and telecommunication services, while Czechia, Hungary and Poland recorded an increase in personal, cultural, and recreational services.

The increase in the RSCA index in the selected human-capital-intensive services could be attributed to the increase in the supply of human capital in the V4 countries, which is reflected by the expansion of tertiary education. Between 2000 and 2018, the share of the population aged 30 to 34 years with tertiary education increased from $13.7 \%$ to $33.7 \%$ in Czechia, from $14.8 \%$ to $33.7 \%$ in Hungary, from $12.5 \%$ to $45.7 \%$ in Poland, and from 10.6\% to 37.7\% in Slovakia. For comparison, between 2002 and 2018, the corresponding share in the EU28 increased from $23.6 \%$ to $40.7 \%$ (Eurostat data).

Should the convergence processes cause a gradual erosion of the cost competitiveness, it will decrease the cost-driven revealed comparative advantages of the V4 countries and create incentives to specialise in human-capital-intensive services.

\subsection{Analysis of sophistication}

\subsubsection{Sophistication of service categories}

The sophistication of service categories is based on supply factors, which makes it broadly stable in the span of a decade. Table 2 presents the results of our findings.

Table 2

Normalised PRODY

\begin{tabular}{|c|c|c|c|c|c|c|c|c|c|}
\hline & 2010 & 2011 & 2012 & 2013 & 2014 & 2015 & 2016 & 2017 & 2018 \\
\hline PRO & 0.08 & 0.12 & 0.12 & 0.08 & 0.14 & 0.17 & 0.19 & 0.22 & 0.25 \\
\hline MAI & 0.20 & 0.20 & 0.21 & 0.17 & 0.19 & 0.20 & 0.24 & 0.24 & 0.26 \\
\hline SEA & 0.39 & 0.40 & 0.39 & 0.39 & 0.41 & 0.42 & 0.43 & 0.45 & 0.46 \\
\hline AIR & 0.25 & 0.27 & 0.29 & 0.29 & 0.31 & 0.33 & 0.33 & 0.35 & 0.36 \\
\hline RAI & 0.00 & 0.01 & 0.05 & 0.07 & 0.08 & 0.10 & 0.12 & 0.15 & 0.17 \\
\hline ROA & 0.08 & 0.09 & 0.14 & 0.11 & 0.13 & 0.14 & 0.15 & 0.16 & 0.18 \\
\hline INL & 0.21 & 0.26 & 0.28 & 0.18 & 0.38 & 0.38 & 0.40 & 0.40 & 0.43 \\
\hline POS & 0.30 & 0.33 & 0.35 & 0.33 & 0.34 & 0.33 & 0.37 & 0.36 & 0.37 \\
\hline TRV & 0.17 & 0.17 & 0.19 & 0.18 & 0.20 & 0.21 & 0.22 & 0.24 & 0.26 \\
\hline CON & 0.25 & 0.24 & 0.22 & 0.22 & 0.27 & 0.31 & 0.34 & 0.34 & 0.41 \\
\hline INS & 0.58 & 0.56 & 0.58 & 0.56 & 0.57 & 0.56 & 0.58 & 0.59 & 0.62 \\
\hline FIN & 0.89 & 0.88 & 0.85 & 0.83 & 0.83 & 0.80 & 0.82 & 0.96 & 1.00 \\
\hline INT & 0.45 & 0.45 & 0.49 & 0.51 & 0.59 & 0.63 & 0.64 & 0.68 & 0.70 \\
\hline TEL & 0.35 & 0.36 & 0.37 & 0.33 & 0.33 & 0.34 & 0.34 & 0.35 & 0.34 \\
\hline COM & 0.33 & 0.35 & 0.46 & 0.35 & 0.47 & 0.52 & 0.50 & 0.37 & 0.36 \\
\hline INF & 0.28 & 0.27 & 0.26 & 0.15 & 0.23 & 0.23 & 0.24 & 0.28 & 0.30 \\
\hline RDI & 0.42 & 0.43 & 0.47 & 0.42 & 0.44 & 0.47 & 0.53 & 0.57 & 0.57 \\
\hline PRF & 0.32 & 0.32 & 0.33 & 0.29 & 0.31 & 0.33 & 0.36 & 0.39 & 0.42 \\
\hline TEC & 0.33 & 0.36 & 0.41 & 0.39 & 0.43 & 0.46 & 0.49 & 0.51 & 0.52 \\
\hline PER & 0.57 & 0.35 & 0.36 & 0.39 & 0.43 & 0.40 & 0.40 & 0.39 & 0.40 \\
\hline
\end{tabular}

Source: own elaboration of the Eurostat data. 
First, it is worth noting that there are a few categories of services that clearly lead in terms of sophistication in the analysed period. These are financial services, followed by insurance and pension services and charges for the use of intellectual property. Other services located at the top of the sophistication ranking include research and development services, technical, trade-related and other business services, as well as sea transport. It is noteworthy that research and development services, along with all the business support services (such as financial services, insurance and pension services, technical, trade-related, and other business services), as well as charges for the use of intellectual property, mostly comprising software and audio-visuals licensing, should be associated with either initial or final linkages of the production chains. According to the concept of the smiling curve (see, e.g. Dedrick, Kraemer \& Shin, 2012; Del Prete \& Rungi, 2018), the initial and the final stages of production processes provide the most value added. Our results suggest that they are also the most complex.

Comparing these results to the RSCA indices calculated for the V4 countries, one can conclude that Czechia and Slovakia did not reveal comparative advantage in any of the most sophisticated services in any of the analysed years. Poland had a positive RSCA in technical, trade-related, and other business services in 2010 and 2011, but since then, it has lost its comparative advantage. Moreover, in 2011 and 2016, Poland had a positive value of the RSCA index in personal, cultural, and recreational services, but that value was close to zero and hence should not be treated as a significant indicator of a comparative advantage. Hungary seems to have had the strongest position among the V4 countries in the most sophisticated service categories in the analysed period. Up to 2016, it revealed a comparative advantage in services associated with charges for the use of intellectual property. Also, apart from 2010, Hungary maintained a positive value of the RSCA index in personal, cultural, and recreational services. All things considered, the V4 countries generally did not reveal comparative advantages in the most sophisticated service categories within the analysed period. If any positive RSCA values were noted, they were either observations for single years, or they gradually declined over time.

It is also possible to determine the services which were the least sophisticated in the analysed period. These include rail and road transport, manufacturing services, travel, and maintenance and repair services. Transport, maintenance and repair services, as well as manufacturing services, are associated with the middle section of the production chain, which is usually characterised by low value added. Our results, therefore, again suggest that sophistication and the creation of value added might be correlated. The V4 countries revealed comparative advantages in all the least sophisticated service categories within the research period.

On the one hand, Table 2 shows that the least sophisticated service categories improved their normalised PRODY values significantly, especially rail (from 0 to 0.17 ), road (from 0.08 to 0.18 - a growth of $125 \%$ ), and inland water transport (from 0.21 to $0.43-105 \%$ ), manufacturing services (from 0.08 to 0.25 $-213 \%$ ), and construction (from 0.25 to $0.41-64 \%$ ). However, some of the most sophisticated services, such as financial services (from 0.89 to $1-12 \%$ ) or insurance and pension services (from 0.58 to $0.62-$ $7 \%$, were less dynamic. While such a blueprint may be considered typical, its scale is quite astonishing. However, this pattern is not always true, since, e.g. research and development services (from 0.42 to 0.57 $36 \%$ ) or charges for the use of intellectual property (from 0.45 to $0.7-55 \%$ ) noted quite an increase, while, e.g. maintenance and repair services (from 0.2 to $0.26-30 \%$ ) or sea transport (from 0.39 to $0.46-18 \%$ ) were relatively stable. However, claiming that there is some convergence of the levels of sophistication is not without substance.

In fact, the distance between the most and the least sophisticated service categories within a particular year diminished from 0.89 in 2010 to 0.7 in 2016. Yet, the stability of this convergence is undermined by the fact that the distance grows back, reaching 0.83 in 2018, which is caused by a rapid shift in the level of PRODY calculated for financial services. However, this might be a result of tax reforms in Ireland, which attracted many financial companies from the United States to move to Ireland, supporting Irish GDP 
growth. According to the Eurostat data, in 2015, the real GDP of Ireland increased by 25\% year-to-year, which resulted in a persistent shift in Irish GDP per capita. This additional product is mostly transferred abroad and could be treated as a sort of statistical artefact. Nevertheless, since PRODY is a form of weighted average GDP per capita, it has been affected. All things considered, there seems to be evidence for convergence between the categories of services in terms of their complexity.

\subsubsection{Sophistication of countries' export of services}

The values of the normalised EXPY (see Table 3) for the V4 countries are low, which implies that there is a substantial gap between the EU countries, which export the most sophisticated services, and the V4 countries. However, the entire distribution is, in fact, skewed. One can observe the clear domination of Luxembourg, while the United Kingdom, Ireland and Cyprus are the closest followers, but with already much lower values of EXPY. Therefore, even though the values of normalised EXPY for the V4 countries are low, they are still relatively close to the median, which is, in fact, determined by the normalised EXPY of Hungary in most years.

Table 3

Normalised EXPY for the EU countries

\begin{tabular}{|l|c|c|c|c|c|c|c|c|c|}
\hline & $\mathbf{2 0 1 0}$ & $\mathbf{2 0 1 1}$ & $\mathbf{2 0 1 2}$ & $\mathbf{2 0 1 3}$ & $\mathbf{2 0 1 4}$ & $\mathbf{2 0 1 5}$ & $\mathbf{2 0 1 6}$ & $\mathbf{2 0 1 7}$ & $\mathbf{2 0 1 8}$ \\
\hline AT & $\mathrm{N} / \mathrm{D}$ & $\mathrm{N} / \mathrm{D}$ & 0.20 & 0.16 & 0.20 & 0.23 & 0.25 & 0.29 & 0.35 \\
\hline $\mathrm{BE}$ & 0.22 & 0.22 & 0.24 & 0.23 & 0.29 & 0.33 & 0.37 & 0.43 & 0.49 \\
\hline $\mathrm{BG}$ & 0.03 & 0.06 & 0.10 & 0.07 & 0.14 & 0.20 & 0.22 & 0.24 & 0.28 \\
\hline $\mathrm{CY}$ & 0.41 & 0.40 & 0.37 & 0.34 & $\mathrm{~N} / \mathrm{D}$ & $\mathrm{N} / \mathrm{D}$ & $\mathrm{N} / \mathrm{D}$ & 0.53 & 0.57 \\
\hline $\mathrm{CZ}$ & 0.10 & 0.11 & 0.15 & 0.12 & 0.17 & 0.20 & 0.23 & 0.27 & 0.32 \\
\hline $\mathrm{DE}$ & 0.26 & 0.27 & 0.31 & 0.27 & 0.31 & 0.35 & 0.38 & 0.43 & 0.48 \\
\hline $\mathrm{DK}$ & 0.13 & 0.13 & 0.16 & 0.12 & 0.16 & 0.19 & 0.22 & 0.26 & 0.33 \\
\hline $\mathrm{EE}$ & 0.12 & 0.11 & 0.14 & 0.10 & 0.15 & 0.18 & 0.22 & 0.26 & 0.31 \\
\hline $\mathrm{EL}$ & 0.05 & 0.05 & 0.08 & 0.05 & 0.08 & 0.10 & 0.13 & 0.16 & 0.21 \\
\hline $\mathrm{ES}$ & $\mathrm{N} / \mathrm{D}$ & $\mathrm{N} / \mathrm{D}$ & 0.14 & 0.11 & 0.15 & 0.18 & 0.21 & 0.24 & 0.29 \\
\hline $\mathrm{FI}$ & $\mathrm{N} / \mathrm{D}$ & $\mathrm{N} / \mathrm{D}$ & $\mathrm{N} / \mathrm{D}$ & 0.23 & 0.29 & 0.35 & 0.37 & 0.40 & 0.44 \\
\hline FR & 0.18 & 0.18 & 0.23 & 0.21 & 0.25 & 0.28 & 0.33 & 0.36 & 0.41 \\
\hline $\mathrm{HR}$ & 0.00 & 0.00 & 0.04 & 0.02 & 0.06 & 0.09 & 0.12 & 0.15 & 0.20 \\
\hline $\mathrm{HU}$ & 0.13 & 0.14 & 0.17 & 0.14 & 0.19 & 0.22 & 0.25 & 0.29 & 0.34 \\
\hline $\mathrm{IE}$ & $\mathrm{N} / \mathrm{D}$ & $\mathrm{N} / \mathrm{D}$ & 0.46 & 0.42 & 0.46 & 0.50 & 0.50 & 0.56 & 0.61 \\
\hline $\mathrm{IT}$ & 0.14 & 0.16 & 0.20 & 0.17 & 0.21 & 0.23 & 0.27 & 0.32 & 0.36 \\
\hline $\mathrm{LT}$ & 0.06 & 0.07 & 0.09 & 0.07 & 0.10 & 0.14 & 0.16 & 0.17 & $\mathrm{~N} / \mathrm{D}$ \\
\hline $\mathrm{LU}$ & 0.83 & 0.80 & 0.77 & 0.74 & 0.77 & 0.76 & 0.79 & 0.95 & 1.00 \\
\hline $\mathrm{LV}$ & 0.22 & 0.21 & 0.22 & 0.19 & 0.23 & 0.26 & 0.29 & 0.32 & 0.37 \\
\hline $\mathrm{MT}$ & $\mathrm{N} / \mathrm{D}$ & $\mathrm{N} / \mathrm{D}$ & $\mathrm{N} / \mathrm{D}$ & $\mathrm{N} / \mathrm{D}$ & $\mathrm{N} / \mathrm{D}$ & 0.48 & 0.51 & $\mathrm{~N} / \mathrm{D}$ & $\mathrm{N} / \mathrm{D}$ \\
\hline $\mathrm{NL}$ & $\mathrm{N} / \mathrm{D}$ & $\mathrm{N} / \mathrm{D}$ & $\mathrm{N} / \mathrm{D}$ & $\mathrm{N} / \mathrm{D}$ & 0.35 & 0.40 & 0.43 & 0.48 & 0.53 \\
\hline $\mathrm{PL}$ & 0.11 & 0.11 & 0.14 & 0.10 & 0.15 & 0.19 & 0.22 & 0.26 & 0.33 \\
\hline $\mathrm{PT}$ & 0.08 & 0.08 & 0.11 & 0.08 & 0.12 & 0.14 & 0.16 & 0.19 & 0.24 \\
\hline RO & $\mathrm{N} / \mathrm{D}$ & $\mathrm{N} / \mathrm{D}$ & $\mathrm{N} / \mathrm{D}$ & 0.11 & 0.17 & 0.21 & 0.24 & 0.27 & 0.34 \\
\hline $\mathrm{SE}$ & 0.21 & 0.22 & 0.27 & 0.27 & 0.34 & 0.38 & 0.39 & 0.42 & 0.47 \\
\hline $\mathrm{SI}$ & 0.09 & 0.09 & 0.12 & 0.09 & 0.13 & 0.17 & 0.19 & 0.23 & 0.28 \\
\hline SK & $\mathrm{N} / \mathrm{D}$ & $\mathrm{N} / \mathrm{D}$ & $\mathrm{N} / \mathrm{D}$ & 0.11 & 0.16 & 0.19 & 0.21 & 0.26 & 0.32 \\
\hline $\mathrm{UK}$ & 0.49 & 0.49 & 0.49 & 0.46 & 0.49 & 0.49 & 0.52 & 0.60 & 0.66 \\
\hline
\end{tabular}

Source: own elaboration of the Eurostat data. 
The data in Table 4 provide a framework for the analysis of the normalised static EXPY. The results of the analysis are not significantly dissimilar to the results for regular EXPY. Again, Hungary has the highest complexity among the V4 countries. However, the static EXPY values in the V4 countries are generally lower than non-static ones and tend to be more stable over time, which indicates that most of the dynamics observed for traditional EXPY in Czechia, Hungary, Poland and Slovakia arose from the growing PRODY. In fact, in all the EU countries, the static EXPY values were close to constant in the analysed period.

These findings support both lines of argumentation on the link between integration and sophistication (see section 2.3). Firstly, in the period broadly spanning 2010 to 2018, the EXPY levels were rising. Due to the so-called base effect, this was mostly observed for countries with lower initial complexity levels. Secondly, when cleansed from the impact of the developments in PRODY levels, the distribution of complexity between the EU countries was notably rigid over time.

Table 4

Normalised static EXPY for the EU countries

\begin{tabular}{|c|c|c|c|c|c|c|c|c|c|}
\hline & 2010 & 2011 & 2012 & 2013 & 2014 & 2015 & 2016 & 2017 & 2018 \\
\hline AT & $\mathrm{N} / \mathrm{D}$ & $\mathrm{N} / \mathrm{D}$ & 0.21 & 0.21 & 0.21 & 0.20 & 0.20 & 0.19 & 0.19 \\
\hline $\mathrm{BE}$ & 0.29 & 0.29 & 0.28 & 0.31 & 0.32 & 0.34 & 0.34 & 0.35 & 0.35 \\
\hline BG & 0.04 & 0.08 & 0.09 & 0.08 & 0.12 & 0.16 & 0.16 & 0.14 & 0.13 \\
\hline $\mathrm{CY}$ & 0.49 & 0.48 & 0.43 & 0.43 & $\mathrm{~N} / \mathrm{D}$ & $\mathrm{N} / \mathrm{D}$ & $\mathrm{N} / \mathrm{D}$ & 0.49 & 0.46 \\
\hline $\mathrm{CZ}$ & 0.14 & 0.15 & 0.15 & 0.16 & 0.16 & 0.16 & 0.16 & 0.16 & 0.16 \\
\hline $\mathrm{DE}$ & 0.34 & 0.36 & 0.36 & 0.36 & 0.35 & 0.36 & 0.36 & 0.36 & 0.35 \\
\hline DK & 0.16 & 0.16 & 0.16 & 0.15 & 0.15 & 0.15 & 0.16 & 0.16 & 0.16 \\
\hline $\mathrm{EE}$ & 0.15 & 0.14 & 0.14 & 0.13 & 0.13 & 0.14 & 0.15 & 0.15 & 0.15 \\
\hline EL & 0.05 & 0.05 & 0.05 & 0.05 & 0.05 & 0.04 & 0.05 & 0.05 & 0.04 \\
\hline ES & $\mathrm{N} / \mathrm{D}$ & $\mathrm{N} / \mathrm{D}$ & 0.14 & 0.13 & 0.13 & 0.13 & 0.14 & 0.13 & 0.13 \\
\hline FI & $\mathrm{N} / \mathrm{D}$ & $\mathrm{N} / \mathrm{D}$ & $\mathrm{N} / \mathrm{D}$ & 0.31 & 0.31 & 0.31 & 0.32 & 0.31 & 0.30 \\
\hline FR & 0.25 & 0.25 & 0.26 & 0.28 & 0.27 & 0.27 & 0.28 & 0.26 & 0.26 \\
\hline HR & 0.00 & 0.00 & 0.01 & 0.00 & 0.01 & 0.02 & 0.02 & 0.02 & 0.03 \\
\hline $\mathrm{HU}$ & 0.20 & 0.20 & 0.20 & 0.19 & 0.18 & 0.18 & 0.19 & 0.18 & 0.18 \\
\hline $\mathrm{IE}$ & $\mathrm{N} / \mathrm{D}$ & $\mathrm{N} / \mathrm{D}$ & 0.56 & 0.55 & 0.53 & 0.53 & 0.51 & 0.52 & 0.51 \\
\hline IT & 0.20 & 0.22 & 0.22 & 0.22 & 0.21 & 0.21 & 0.22 & 0.22 & 0.21 \\
\hline LT & 0.07 & 0.07 & 0.07 & 0.09 & 0.07 & 0.09 & 0.10 & 0.06 & $\mathrm{~N} / \mathrm{D}$ \\
\hline LU & 1.00 & 0.99 & 0.98 & 0.96 & 0.97 & 0.99 & 0.98 & 0.99 & 0.97 \\
\hline $\mathrm{LV}$ & 0.26 & 0.26 & 0.24 & 0.24 & 0.25 & 0.26 & 0.26 & 0.24 & 0.23 \\
\hline MT & $\mathrm{N} / \mathrm{D}$ & $\mathrm{N} / \mathrm{D}$ & $\mathrm{N} / \mathrm{D}$ & $\mathrm{N} / \mathrm{D}$ & $\mathrm{N} / \mathrm{D}$ & 0.59 & 0.59 & $\mathrm{~N} / \mathrm{D}$ & $\mathrm{N} / \mathrm{D}$ \\
\hline $\mathrm{NL}$ & $\mathrm{N} / \mathrm{D}$ & $\mathrm{N} / \mathrm{D}$ & $\mathrm{N} / \mathrm{D}$ & $\mathrm{N} / \mathrm{D}$ & 0.38 & 0.39 & 0.39 & 0.39 & 0.39 \\
\hline PL & 0.15 & 0.15 & 0.14 & 0.14 & 0.14 & 0.15 & 0.15 & 0.16 & 0.16 \\
\hline PT & 0.09 & 0.10 & 0.10 & 0.10 & 0.09 & 0.09 & 0.08 & 0.07 & 0.07 \\
\hline $\mathrm{RO}$ & $\mathrm{N} / \mathrm{D}$ & $\mathrm{N} / \mathrm{D}$ & $\mathrm{N} / \mathrm{D}$ & 0.16 & 0.16 & 0.16 & 0.17 & 0.16 & 0.18 \\
\hline $\mathrm{SE}$ & 0.31 & 0.32 & 0.32 & 0.36 & 0.38 & 0.38 & 0.36 & 0.34 & 0.33 \\
\hline SI & 0.11 & 0.12 & 0.11 & 0.11 & 0.11 & 0.12 & 0.12 & 0.12 & 0.12 \\
\hline SK & $\mathrm{N} / \mathrm{D}$ & $\mathrm{N} / \mathrm{D}$ & $\mathrm{N} / \mathrm{D}$ & 0.15 & 0.15 & 0.15 & 0.15 & 0.16 & 0.16 \\
\hline UK & 0.62 & 0.63 & 0.61 & 0.61 & 0.58 & 0.57 & 0.57 & 0.56 & 0.57 \\
\hline
\end{tabular}

Source: own elaboration of the Eurostat data.

\subsection{Discussion}

The values of normalised static EXPY for the V4 countries in the 2010-2018 period, despite being low, are close to the centre of the distribution, but the distribution is strongly right-skewed (the skewness 
coefficient is over 1.85) and leptokurtic (the kurtosis coefficient of about 3.82 indicates a relatively "fat tail" compared to a normal distribution $\left.{ }^{5}\right)$. Figure 5 presents a schematic overview of that distribution.

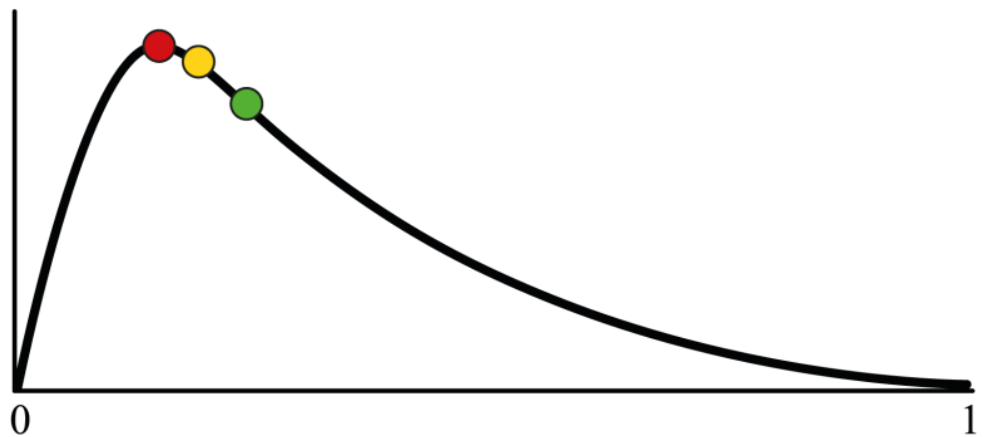

Figure 5. Visual outline of the distribution of normalised static EXPY in 2010-2018

The red point indicates the mode (0.16), the yellow point indicates the median (0.18), and the green point indicates the average (0.26).

Source: own elaboration

These findings place Czechia, Hungary, Poland and Slovakia in a rather pessimistic light. Dropping Luxembourg, an obvious outlier, from the sample does not change the general characteristics of the distribution, which remains right-skewed and leptokurtic. Metaphorically speaking, the V4 countries remain in the middle of the peloton, but the leaders are far ahead.

Let us recall that the PRODY index is based on averaging the real GDP per capita levels of countries that export certain services, while EXPY is based on averaging PRODY. As a result, one could treat EXPY as a hypothetical level of GDP per capita calculated upon the country's export structure. It is, therefore, interesting to compare the levels of EXPY (unnormalized, but static) and the levels of real GDP per capita in the EU member states (Figure ). This should make it possible to determine whether the distance between the V4 and most developed European economies is larger in terms of complexity or income.

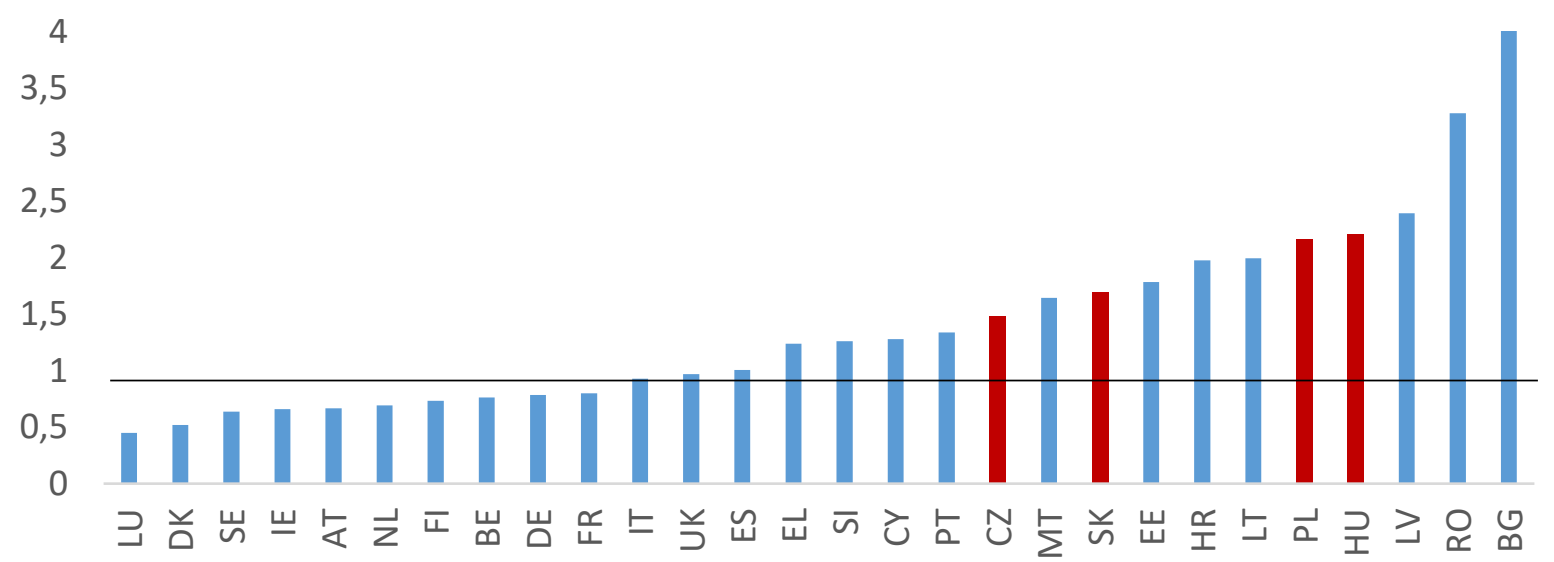

Figure 6. Static EXPY to real GDP per capita ratio, average for 2010-2018

Source: own elaboration of the Eurostat data.

\footnotetext{
5 The kurtosis coefficient has two alternative standard presentations, one of which includes subtracting 3 from the final result and the other does not. Depending on the selected version, the kurtosis of a normal distribution is either 0 or 3 . The presented result should be compared to 0 ; therefore the leptokurtosis of the distribution is, in fact, relatively strong.
} 
It turns out that it is the less sophisticated exporters that note a higher ratio of unnormalised EXPY to real GDP per capita. The ratio in all of the V4 countries is above 1, which implies that their service exports are more sophisticated than their real GDP per capita levels would suggest. Thus, in terms of economic complexity, Czechia, Hungary, Poland and Slovakia are relatively closer to the leaders than in terms of GDP per capita. If economic complexity triggers all the positive development mechanisms, as presented in section 2.2, then this might be a chance for the V4 countries to catch up with the most developed partners. Even in its current structure, international trade in services is beneficial to the V4 countries, and one could recommend supporting it as a minimum plan.

Should the authorities of given states aspire to even better results, they would have to engage in sectoral policies, providing additional assistance to the relatively highly sophisticated services. Looking at the data in Table 2, financial and insurance services stand out as the most complex. However, none of the V4 countries is close to obtaining a revealed comparative advantage in these services; therefore, focusing on them might be impractical. It seems that it would be more appropriate to concentrate on the "second best" solution, so not the most sophisticated, but still relatively complex services, i.e., services associated with research and development (RDI), and charges for intellectual property (INT), as well as technical, trade-related, and other business services (TEC). In fact, in all of these categories, relatively low wages, characteristic of the V4 countries, might be a supporting catalyst at the beginning of the development of these services. In time, growing human capital should translate to higher wage demands, but as long as productivity follows, that would not be an obstacle.

In that context, Hungary is the closest to securing a comparative advantage in all three categories, while Czechia is on the edge of actually having an advantage in RDI and close in TEC. Poland is close to succeeding in RDI and TEC as well, but one must notice that in the last decade, Poland had an advantage in TEC but lost it. The worst situation is in Slovakia, whose RSCA is far from positive in any of the three service categories of interest, and it does not note an improvement in these sectors either.

Our research period was limited by the available data on international trade in services. Typically, one would extrapolate any observed trends onto the following years in order to predict the development of export of services from the V4 countries in the near future. However, it is painfully clear now that the Covid-19 pandemic will provide a shift to many national output and export structures. Let us notice that Czechia and Slovakia have advantages in computer services and telecommunications; Poland is close to having an advantage in the former category and has improved in the latter. So the pandemic, despite being an adverse shock, may open some opportunities as well. Hungary, on the other hand, specialises in all kinds of transportation services, as well as services associated with travelling and recreation. Therefore, it seems that Hungary is particularly vulnerable to the damage caused by the pandemic crisis.

\section{CONCLUSION}

This paper investigated the specialisation and complexity of the exports of services of V4 countries, compared to the EU between 2010 and 2018. It found that the V4 countries were relatively specialised in the export of labour-intensive services, including rail and road transport, manufacturing services or maintenance and repair services. Moreover, the V4 countries decreased their comparative disadvantages or began to reveal comparative advantages in selected human-capital-intensive services.

In general, the V4 countries specialise in non-sophisticated services. Yet, at the same time, their exports of services are more sophisticated than their real GDP per capita would suggest. Moreover, the service export complexity of the V4 countries is rising. This is due to the convergence of sophistication levels between service categories rather than shifts in the structure of services exported by the V4 countries. However, it 
still provides an opportunity to catch up with more developed partners if the authorities focus on supporting relatively complex services that are already significantly present in the economic structures of the V4 countries, such as research and development or business support services.

After controlling for the convergence and focusing on the structure of export, the relative distribution of service export complexity among European countries turns out to be quite steady, which is consistent with the rather stable revealed comparative advantages. Some positive changes were also observed, and paradoxically, developments in computer services and telecommunication may even have been stimulated by the Covid-19 pandemic.

Finally, our results suggest that the sophistication and creation of value added might be positively correlated. The verification of this hypothesis is an interesting area for future research.

\section{REFERENCES}

Anand R., Mishra S., \& Spatafora N. (2012). Structural Transformation and the Sophistication of Production. IMF Working Paper No. 12/59.

Anand R., Mishra, S., \& Lundstrom, S. (2011). Service Export Sophistication and Economic Growth. World Bank Policy Research Working Paper 5606.

Antras P., \& Foley F.C. (2011). Regional Trade Integration and Multinational Firm Strategies, in: Costs and Benefits of Economic Integration in Asia (pp. 208-240), Barro R., Lee J.W. (ed.), Oxford, Oxford University Press.

Antras P., \& Helpman E. (2004). Global Sourcing. Journal of Political Economy 112(3), 552-580.

Balance of Payments and International Investment Position Manual (6 $6^{\text {th }}$ ed.) (2009). International Monetary Fund.

Balassa B. (1965). Trade liberalisation and 'Revealed Comparative Advantage'. The Manchester School 33(2), 99-123.

Breinlich H., \& Criscuolo C. (2011). International trade in services: A portrait of importers and exporters. Journal of International Economics 84(2), 188-206.

Canh, N. P., Schinckus, C., \& Thanh, S. D. (2020). The natural resources rents: Is economic complexity a solution for resource curse?. Resources Policy, 69, 101800.

Canoy M., \& Smith P.M. (2008). Services and the Single Market. Journal of Industry, Competition and Trade 8(3-4), 319347.

Costinot A., Donaldson D., \& Komunjer I. (2010). What Goods Do Countries Trade? A Quantitative Exploration of Ricardo's Ideas. Review of Economic Studies 79, 581-608.

Crozet M., Milet E., \& Mirza D. (2016). The impact of domestic regulations on international trade in services: Evidence from firm-level data. Journal of Comparative Economics 44(3), 585-607.

Dedrick J., Kraemer K.L., \& Shin N. (2012). Value Capture in the Global Electronics Industry: Empirical Evidence for the "Smiling Curve" Concept. Industry and Innovation 19(2), 89-107.

Del Prete D., \& Rungi A. (2018). The smile curve at the firm level: Where value is added along supply chains. Economics Letters, 164, 38-42.

Eck K., \& Huber, S. (2016). Product sophistication and spillovers from foreign direct investment. Canadian Journal of Economics, 49(4), 1658-1684.

Foster N., Hunya G., Pindyuk O., \& Richter S. (2011). Revival of the Visegrad Countries'Mutual Trade after their EU Accession: a Search for Explanation. Vienna Institute for International Economic Studies, Research Report No. 372, 77-91.

Freund C., \& Weinhold D. (2002). The Internet and International Trade in Services. American Economic Review 92(2), 236-240.

Gable S., \& Mishra S. (2011). Service Export Sophistication and Europe's New Growth Model, World Bank Policy Research Working Paper 5793.

Gabrielczak P., \& Serwach T. (2017). The impact of the euro adoption on the complexity of goods in Slovenian exports. Zbornik radova Ekonomskog fakulteta u Rijeci : časopis za ekonomsku teoriju i praksu 1(35), 45-71.

Gabrielczak P., \& Serwach T. (2019). Economic Integration and Export Complexity: The Case of Slovakia. Ekonomický casopis 67, 115-134. 
Gabrielczak P. \& Serwach T. (2020). Does the euro increase the complexity of exported goods? The case of Estonia. Journal of Baltic Studies 1(51).Galor O., Mountford A. (2008).Trading Population for Productivity: Theory and Evidence. Review of Economic Studies 75(4), 105-124.

Harding T., \& Javorcik B. (2012). Foreign Direct Investment and Export Upgrading. Review of Economics and Statistics 94(4), 964-980.

Hausmann R., Hwang J., \& Rodrik D. (2007). What you export matters. Journal of Economic Growth 12(1), 1-25.

Helpman E., Melitz M., \& Yeaple S.R. (2004). Export Versus FDI with Heterogeneous Firms. American Economic Review 94(1), 300-316.

Hidalgo C.A., \& Hausmann R. (2009). The building blocks of economic complexity. Proceedings of the National Academy of Sciences 106(26), 10570-10575.

Huber S. (2017). Indicators of Product Sophistication and Factor Intensities: Measurement Matters. Journal of Economic and Social Measurement 42(1), 27-65.

Javorcik B.S., Lo Turco A., \& Maggioni D. (2018). New and Improved: Does FDI Boost Production Complexity in Host Countries?. The Economic Journal 128(614), 2507-2537.

Jensen J.B. (2008). Trade in High-Tech Services. Journal of Industry, Competition and Trade 8(3-4), 181-197.

Koren M., \& Tenreyro S. (2013). Technological Diversification. The American Economic Review 103(1), 378-414.

Krugman P.R., \& Obstfeld M. (2009). International Economics. Theory and Policy (8 ${ }^{\text {th }}$ ed.), Boston: Pearson.

Kuczewska J., \& Stefaniak-Kopoboru J. (2016). Export Specialization in Services of the Visegrad Countries. Equilibrium. Quarterly Journal of Economics and Economic Policy 11(2), 265-284.

Lall S. (2000). The Technological Structure and Performance of Developing Country Manufactured Exports, 1985-98. Oxford Development Studies 28(3), 337-369.

Lall S., Weiss J. \& Zhang J. (2006). The ‘Sophistication' of Exports: A New Trade Measure. World Development 34(2), 222-237.

Laursen K. (1998). Revealed Comparative Advantage and the Alternatives as Measures of International Specialisation. Danish Research Unit for Industrial Dynamics, Working Paper No. 98-30, 1-14.

Lee K.-K., \& Vu T.V. (2020). Economic complexity, human capital and income inequality: a cross-country analysis. The Japanese Economic Review 71, 695-718.

Lehmann A., Tamirisa N.T., \& Wieczorek J. (2003). International Trade in Services: Implications for the IMF, IMF Policy Discussion Paper PDP/03/6.

Maskus K.A. (2008). The Globalization of Intellectual Property Rights and Innovation in Services. Journal of Industry, Competition and Trade 8(3-4), 247-267.

Matuszczak L. (2015). Konkurencyjność polskiego eksportu usług. Wiadomości statystyczne 1, 76-93.

Melitz M. (2003). The Impact of Trade on Intra-Industry Reallocations and Aggregate Industry Productivity. Econometrica 71(6), 1695-1725.

Michaely M., (1984). Trade, Income Levels, and Dependence, Amsterdam: Elsevier Science Ltd.

Morikawa M. (2019). Firm heterogeneity and international trade in services. The World Economy 42(1), 268-295.

Ricardo D. (1817). The Principles of Political Economy and Taxation, London: John Murray.

Romero, J. P., \& Gramkow, C. (2021). Economic complexity and greenhouse gas emissions. World Development, 139, 105317.

Sadeghi P., Shahrestani H., Kiani K.H., \& Torabi T. (2020). Economic Complexity, Human Capital, and FDI Attraction: A Cross Country Analysis. International Economics 164, 168-182.

Sauvé P., Shingal A. (2016). Why Do Economies Enter into Preferential Agreements on Trade in Services? Assessing the Potential for Negotiated Regulatory Convergence in Asian Services Markets. Asian Development Review 33(1), 56-73.

Sepehrdoust, H., Davarikish, R., \& Setarehie, M. (2019). The knowledge-based products and economic complexity in developing countries. Heliyon, 5(12), e02979.

Serwach T., \& Gabrielczak P. (2021). Does European Integration Make Exports More Complex?. Argumenta Oeconomica 1(46), 155-168.

Shieh M.C. (2020). Services Export and Economic Growth: A Panel Cointegration Approach. International Journal of Business and Economics, 2(5), 66-82. 
Vu, T. V. (2020). Economic complexity and health outcomes: A global perspective. Social Science \& Medicine, 265, 113480.

World Trade Report 2019. The Future of Services Trade (2019). World Trade Organization.

Xu B., \& Lu J. (2006). The impact of foreign firms on the sophistication of Chinese exports. China Economic Revien 20(3), 482-493.

Young A. (1991). Learning by Doing and the Dynamic Effects of International Trade. Quarterly Journal of Economics 106(2), 369-405.

Young A. (2014). Structural Transformation, the Mismeasurement of Productivity Growth and the Cost Disease of Services. American Economic Review, 104(11), 3635-3667.

Zhang S., \& Chen C. (2020). Does Outward Foreign Direct Investment Facilitate China's Export Upgrading?. China \& World Economy, 5(28), 64-89. 